\title{
RESPONSABILIDADE TRIBUTÁRIA SOB O ENFOQE DA SÚMULA 435 DO STJ
}

\section{TAX RESPONSIBILITY UNDER THE STJ SUMMARY 435 APPROACH}

\section{FABIO PALLARETTI CALCINI}

Doutor e Mestre em Direito do Estado pela PUC/SP. Especialista em Direito Tributário pelo IBET. Pos Doutorando em Direito Fiscal pela Universidade de Coimbra/POR. Advogado. Ex-Conselheiro do CARF/MF. Professor do IBET e FGV DIREITO SP.

\section{JULIANA CAMPOS DE CARVALHO CRUZ}

Advogada em Sergipe. Especialista em Direito Tributário pelo IBET/BA. Conselheira Titular da Segunda Câmara e do Pleno do Conselho de Contribuintes da Secretaria da Fazenda do Estado de Sergipe. Ex-Conselheira do Conselho Administrativo de Recursos Fiscais da Receita Federal da 2 ${ }^{\mathrm{a}}$ Seção, $3^{\mathrm{a}}$ Câmara, $2^{\mathrm{a}}$ Turma Ordinária.

\section{RESUMO}

Este artigo propõe a fazer uma crítica a respeito da imputação da responsabilidade tributária a sócios e administradores com amparo na Súmula no 435 do STJ expedida com base em uma interpretação equivocada da norma do artigo 135, inciso III, do CTN, em claro desrespeito à lei complementar e à Constituição Federal.

PALAVRAS-CHAVE: Tributo; Responsabilidade Tributária; Terceiros. 


\begin{abstract}
This article proposes to make a critique regarding the imputation of the tax responsibility to members and administrators based in the Precedent ํㅡ 435 of the STJ issued based on a misconception of the rule of the article 135, subsection III, of the CTN, in clear disregard of the complementary law and the Federal Constitution.
\end{abstract}

KEYWORDS: Tax; Liability; Others People.

\title{
INTRODUÇÃO
}

A responsabilidade dos sócios na seara tributária tem sido um tema bastante discutido em todos os Tribunais do país, inclusive na seara administrativa.

Várias interpretações vêm sendo dada ao art. 135 do Código Tributário Nacional e como forma de consolidar o entendimento, em 14.04.2010, foi expedida a Súmula 435 do STJ possibilitando presumir que a empresa tenha sido dissolvida irregularmente quando deixa de funcionar no seu domicílio fiscal, sem comunicação prévia aos órgãos competentes, por causa disso, legitima o redirecionamento da obrigação tributária para o sócio-gerente.

Esta Súmula vem sendo aplicada pelos Tribunais (Judiciais e Administrativos) de forma equivocada, porquanto em que pese justificar-se diante da norma instituída no Código Tributário Nacional (art. 135), dela se dissocia pela falta de coerência do fato que gera a responsabilização do sócio.

$O$ assunto deve ser tratado com parcimônia ressaltando a regra matriz de incidência tributária de modo a evitar interpretações distorcidas e, com isso, provocar prejuízos às pessoas físicas integrantes do quadro societário da empresa devedora. 


\section{DA RESPONSABILIDADE TRIBUTÁRIA NA CONSTITUIÇÃO FEDERAL DE 1988}

A análise da sujeição passiva tributária deve partir da interpretação das normas constitucionais. Isto porque, a Constituição Federal ao delimitar a regra matriz de incidência tributária dos impostos trouxe, implicitamente, os dados para caracterização do sujeito passivo de modo a evitar que o legislador infraconstitucional atribua a qualquer um a obrigação tributária. Dentro desse raciocínio, não poderia exigir o IPI (Imposto sobre Produto Industrializado) daquele sujeito que presta serviço (ex: contador, advogado).

A delimitação da responsabilidade tributária está vinculada à observância ao princípio da capacidade contributiva (art. 145, §1 da Constituição Federal), ao princípio da segurança jurídica e da não surpresa; ao princípio da legalidade (art. 150, inciso I, da Constituição Federal) e, não menos importante, ao princípio do nãoconfisco (art. 150, inciso IV, da Constituição Republicana).

De acordo com o art. 145, $\S^{1}$ a Constituição Federal, sempre que possível, os impostos terão caráter pessoal e serão graduados segundo a capacidade econômica do contribuinte, facultado à administração tributária, especialmente para conferir efetividade a esses objetivos, identificar, respeitados os direitos individuais e nos termos da lei, o patrimônio, os rendimentos e as atividades econômicas do contribuinte. Tal como prescrito, será sujeito passivo quem realizou o fato tributável.

Os critérios identificadores da regra matriz de incidência tributária vinculam o critério material à sujeição passiva impondo àquele que realizou o fato o ônus em suportar a obrigação tributária. Como exemplo: o contribuinte do ICMS é aquele que realizou a circulação de mercadoria, recebeu pela operação, logo, demonstrou sinais de riqueza. Por isso, será o responsável pelo recolhimento do imposto estadual.

Nesta linha esclarece Maria Rita Ferragut (2005, p.40):

Portanto, o princípio da capacidade contributiva exige que a regra-matriz de incidência tributária descreva, no critério material de seu antecedente, um comportamento pessoal que denote sinal de riqueza, e que prescreva, em seu consequente, uma relação jurídica em que o sujeito passivo seja ou o 
titular dessa riqueza ou um outro sujeito qualquer indiretamente relacionado a ela (riqueza), ou ainda direta ou indiretamente relacionado ao seu titular. O sujeito passivo será obrigado a entregar ao sujeito ativo parcela desse montante, a título de tributo.

Bem por isso, afirma Renato Lopes Becho (2014, p.21):

[...], não há autorização para a eleição de outro sujeito passivo pela norma inconstitucional, que não aqueles que realizam a materialidade prevista constitucionalmente.[...] Eles balizam a cobrança do tributo partindo-se do núcleo máximo possível, que é a realização do critério material.[...]

Como consequência da capacidade contributiva, o princípio da segurança jurídica e da não surpresa elege à categoria de sujeito passivo aquele que materializou a hipótese de incidência para o fim de garantir a previsibilidade da cobrança. Desse modo, aquele que realizou a circulação da mercadoria, de certo, será indicado a ocupar a sujeição passiva da relação jurídico-tributária (fato gerador).

O Ministro Maurício Corrêa, ao analisar a ADI o 1102, deixou sedimentado o entendimento segundo o qual não poderia ser sujeito passivo da exação aquele que não realizou o fato tributário. De acordo com o leading case, autônomos e administradores por não receberem salário, tal como prescrito pelo art. 195, inciso I, alínea 'a', da Constituição Federal/1988'1', com redação anterior à Emenda Constitucional no 20/98, não poderiam ser surpreendidos com a cobrança da contribuição patronal prevista no art. $3^{\circ}$, inciso I, da Lei $n^{0} 7.787 / 89^{2}$ cuja a norma foi declarada inconstitucional.

O princípio da legalidade prescrito no art. 150 , inciso I, da Constituição Federal vem como medida protetiva à responsabilização tributária do sujeito passivo na medida que a vincula às regras de competências. Se o ISSQN deve ser instituído

\footnotetext{
1 "Art. 195. A seguridade social será financiada por toda a sociedade, de forma direta e indireta, nos termos da lei, mediante recursos provenientes dos orçamentos da União, dos Estados, do Distrito Federal e dos Municípios, e das seguintes contribuições sociais: I - dos empregadores, incidente sobre a folha de salários, o faturamento e o lucro;..."

2 "Art. 3‥ A contribuição das empresas em geral e das entidades ou órgãos a ela equiparados, destinada à Previdência Social, incidente sobre a folha de salários, será: ...I - de $20 \%$ sobre o total das remunerações pagas ou creditadas, a qualquer título, no decorrer do mês, aos segurados empregados, avulsos, autônomos e administradores;"
} 
por lei e o sujeito passivo está vinculado à materialidade do tributo, o imposto é devido tão somente por aquele que prestou o serviço.

Interessante notar o voto proferido pelo Min. Mauro Campbell Marques, no julgamento do REsp no 1.541.275/PR, em 17.12.2015, onde ressaltou a importância do princípio da legalidade na definição de todos os critérios da hipótese de incidência da contribuição sindical rural (imposto sindical), notadamente o critério pessoal, definindo os sujeitos ativos e passivos da exação:

\begin{abstract}
PROCESSUAL CIVIL. TRIBUTÁRIO. CONTRIBUIÇÃO SINDICAL RURAL. AÇÃO CIVIL PÚBLICA. ILEGITIMIDADE DO MINISTÉRIO PÚBLICO. ART. 10, PARÁGRAFO ÚNICO, DA LEI N. 7.347/85. [....] 2. Ocorre que a contribuição sindical rural compulsória (imposto sindical) é tributo e, como tal, submetida ao princípio da legalidade tributária a definir todos os critérios de sua hipótese de incidência, notadamente o critério pessoal da hipótese de incidência onde estão estabelecidos os sujeitos ativos e passivos da exação (estes últimos conforme seu fato-signo presuntivo de riqueza), no caso delimitados pelo art. 10 do Dec.-Lei n. 1.166/71). [....] 4. Recurso especial da FEDERAÇÃO DA AGRICULTURA DO ESTADO DO PARANÁ FAEP e recurso especial da CONFEDERAÇÃO NACIONAL DA AGRICULTURA E PECUÁRIA DO BRASIL - CNA providos. (STJ, 2015, online).
\end{abstract}

Não bastando, o princípio do não confisco assegura que a cobrança do tributo não seja confiscatória e atenda ao princípio da capacidade contributiva, pois, se qualquer pessoa pudesse ser obrigada a pagar tributos por conta de fatos praticados por outras, com quem não detivessem qualquer espécie de vínculo (com a pessoa ou com o fato), o tributo teria grandes chances de se tornar confiscatório, já que poderia incidir sobre o patrimônio do obrigado e não sobre a manifestação de riqueza ínsita ao fato constitucionalmente previsto (FERRAGUT, 2007, p.14).

Não é por outra razão que o art. 121, parágrafo único, inciso I, do Código Tributário Nacional dispõe que o sujeito passivo da obrigação principal se diz contribuinte, quando possui relação pessoal e direta com o fato gerador.

A supremacia constitucional impõe uma limitação ao legislador infraconstitucional na escolha do sujeito passivo. Neste sentido, o Min. Gilmar Mendes, por ocasião do julgamento do Al 738.163 AgR-ED, afirmou que os 
Municípios ao instituírem o ISSQN deveriam observar os parâmetros materiais da Constituição Federal e da lei complementar ${ }^{3}$ na indicação do sujeito passivo ${ }^{4}$.

É fato que alguns tributos não possuem a materialidade especificada na Constituição Federal, a exemplo: taxa, contribuição de melhoria ${ }^{5}$ e impostos de competência residual ${ }^{6}$. Ainda assim, a imputação da responsabilidade de terceira pessoa (não contribuinte) não foge à regra e, mais uma vez, a materialidade do tributo é associada à sujeição passiva.

Não é demais citar, como exemplo, a taxa de vigilância sanitária instituída pelo art. 23 da Lei o 9.782/99. De acordo com a norma, a exação é devida por pessoa física e jurídica que exerça atividade de fabricação de cosmético. Neste contexto, a norma indica como fato gerador (materialidade do tributo) a prática de atos de competência da Agência Nacional de Vigilância Sanitária (órgão responsável pela fiscalização). Aquele que realiza o fato gerador (da hipótese de incidência da taxa - de fiscalização) está obrigado ao recolhimento do referido tributo.

A responsabilidade tributária também pode ser analisada na ótica de terceiros não contribuintes. A despeito de inexistir relação direta e pessoal com o fato gerador, nem por isso o legislador infraconstitucional teria ampla liberdade de apontar qualquer sujeito para integrar a relação jurídico-tributária. Permanece a vinculação do terceiro (não-contribuinte) à materialidade do tributo. A Carta Republicana reconhece a sua existência e o vincula ao fato gerador. Dispõe o art. 150, $\S 7^{\circ}$ da CF:

\footnotetext{
${ }^{3} \mathrm{CF}$, Art. 146. Cabe à lei complementar: ...III - estabelecer normas gerais em matéria de legislação tributária, especialmente sobre: a) definição de tributos e de suas espécies, bem como, em relação aos impostos discriminados nesta Constituição, a dos respectivos fatos geradores, bases de cálculo e contribuintes;

${ }^{4}$ Al 738.163 AgR-ED, voto do rel. min. Gilmar Mendes, j. 15-2-2011, 2 ${ }^{\mathrm{a}} \mathrm{T}$, DJE de 1--3-2011.

5 Os proprietários de imóveis situados nas zonas beneficiadas pelas obras públicas - decreto lei oㅡ $195 / 67$.

${ }^{6}$ Art. 154. A União poderá instituir: I - mediante lei complementar, impostos não previstos no artigo anterior, desde que sejam não-cumulativos e não tenham fato gerador ou base de cálculo próprios dos discriminados nesta Constituição; II - na iminência ou no caso de guerra externa, impostos extraordinários, compreendidos ou não em sua competência tributária, os quais serão suprimidos, gradativamente, cessadas as causas de sua criação. Art. 195. A seguridade social será financiada por toda a sociedade, de forma direta e indireta, nos termos da lei, mediante recursos provenientes dos orçamentos da União, dos Estados, do Distrito Federal e dos Municípios, e das seguintes contribuições sociais: ... § $4^{\circ} \mathrm{A}$ lei poderá instituir outras fontes destinadas a garantir a manutenção ou expansão da seguridade social obedecido, o disposto no art. 154, I.
} 
Art. 150. Sem prejuízo de outras garantias asseguradas ao contribuinte, é vedado à União, aos Estados, ao Distrito Federal e aos Municípios: [...] § 7oㅡㄴ A lei poderá atribuir a sujeito passivo de obrigação tributária a condição de responsável pelo pagamento de imposto ou contribuição, cujo fato gerador deva ocorrer posteriormente, assegurada a imediata e preferencial restituição da quantia paga, caso não se realize o fato gerador presumido. (grifo nosso).

$O$ art. 150, $\S 7^{\circ}$ da Constituição Federal não deixa passar a necessidade de indicar o terceiro observando o fato gerador que fez surgir a obrigação tributária.

Não é por outra razão que o art. 128 do Código Tributário Nacional, em consonância ao disposto no art. 146, inciso III, alínea 'a', da CF/88, permite a responsabilização de terceira pessoa pelo recolhimento do crédito tributário desde que vinculada ao fato gerador.

Mais adiante, este tema será abordado com ênfase na lei complementar para o fim de alcançar o estudo aqui proposto, qual seja, demonstrar que a Súmula no 435 do STJ embora advenha da interpretação dada ao art. 135, inciso III, do Código Tributário Nacional, dela se dissocia completamente.

\section{DA RESPONSABILIDADE TRIBUTÁRIA NO CÓDIGO TRIBUTÁRIO NACIONAL}

De acordo com o art. 146, inciso III, alínea 'a' da Constituição Federal cabe a lei complementar estabelecer normas gerais em matéria de legislação tributária, especialmente, definição de tributos e suas espécies, bem como, em relação aos impostos discriminados na Constituição, a dos respectivos fatos geradores, bases de cálculo e contribuintes.

Seguindo o comando constitucional, a lei complementar (Código Tributário Nacional ${ }^{7}$ ), estabelece no art. 121 que o sujeito passivo deve ter ligação com o fato gerador. Se esta relação for pessoal e direta, diz-se contribuinte (inciso I). Se não

7 O Código Tributário Nacional, instituído pela Lei ํㅡ 5.172/66, foi recepcionado pela Constituição Federal de 1988 com o status de lei complementar por força da publicação do art. $7^{\circ}$ do Ato Complementar $\mathrm{n}^{\circ} 36 / 67$. 
revestir a condição de contribuinte, mas se a obrigação decorrer de lei, diz-se terceiro (inciso II).

Sem deixar de lado a importância da figura do contribuinte na relação jurídico-tributária, mas forçando delimitar o objeto de estudo da sujeição passiva ao disposto no art. 121, inciso II, do CTN (terceiro não-contribuinte), importa relembrar o entendimento exposto no tópico anterior deste artigo no sentido de vincular a responsabilidade pelo adimplemento do crédito tributário ao fato gerador.

Neste ínterim, dispõe o art. 128 do CTN que a lei pode atribuir de modo expresso a responsabilidade pelo crédito tributário a terceira pessoa, vinculada ao fato gerador da respectiva obrigação, excluindo a responsabilidade do contribuinte ou atribuindo a este em caráter supletivo:

Art. 128. Sem prejuízo do disposto neste capítulo, a lei pode atribuir de modo expresso a responsabilidade pelo crédito tributário a terceira pessoa, vinculada ao fato gerador da respectiva obrigação, excluindo a responsabilidade do contribuinte ou atribuindo-a a este em caráter supletivo do cumprimento total ou parcial da referida obrigação. (grifo nosso)

O terceiro responsável é o sujeito vinculado ao fato gerador (1\% requisito), sua obrigação decorre de lei ( $2^{\circ}$ requisito) e deve ser enquadrado em uma das hipóteses previstas na lei complementar (sucessores, terceiros e por infrações).

$\mathrm{Na}$ relação jurídico-tributária a responsabilidade pelo adimplemento da obrigação tributária sempre estará vinculada ao fato gerador. Se contribuinte, a vinculação será direta e pessoal, enquanto o responsável, não obstante seja indireta, é necessária para legitimar a sujeição passiva, daí porquê afirma Hugo de Brito Machado (2015, p.115/122):

O sujeito passivo da obrigação tributária é sempre uma pessoa vinculada de algum modo ao fato gerador correspondente. O vínculo do contribuinte há de ser pessoal e direto, enquanto o vínculo do responsável pode ser indireto, mas é necessário. Por isto mesmo o Código Tributário Nacional, ao cuidar da responsabilidade tributária, diz que a lei pode atribuir de modo expresso a responsabilidade pelo critério tributário a terceira pessoa, vinculada ao fato gerador da respectiva obrigação, excluindo-se a responsabilidade do contribuinte ou atribuindo-se a este em caráter supletivo do cumprimento total ou parcial da referida obrigação. 
Nos arts. 129 a 133 do CTN foram catalogadas as hipóteses de responsabilidade de sucessores. Os arts. 134 e 135 do CTN dispõem sobre a responsabilidade de terceiros e, por fim, nos arts. 137 e 138 a responsabilidade por infrações sob o aspecto da tipicidade penal.

Através do exame do art. 135 da lei complementar, posteriormente, de forma mais precisa, do seu inciso III, será realizada uma crítica às interpretações maliciosas que vêm desfigurando a regra matriz da responsabilidade de terceiros, fazendo surgir, de forma equivocada, uma nova sujeição passiva sem qualquer previsão legal.

\subsection{DA RESPONSABILIDADE DE TERCEIROS.}

Estabelece o art. 135 do CTN que são pessoalmente responsáveis pelos créditos correspondentes a obrigações tributárias resultantes de atos praticados com excesso de poderes ou infração de lei, contrato social ou estatutos as pessoas referidas no art. 134 (inciso I), os mandatários, prepostos e empregados (inciso II) e, por fim, os diretores, gerentes ou representantes de pessoas jurídicas de direito privado (inciso III):

Art. 135. São pessoalmente responsáveis pelos créditos correspondentes a obrigações tributárias resultantes de atos praticados com excesso de poderes ou infração de lei, contrato social ou estatutos: I - as pessoas referidas no artigo anterior; II - os mandatários, prepostos e empregados; III - os diretores, gerentes ou representantes de pessoas jurídicas de direito privado.

O caput do artigo traz em seu bojo a regra-matriz da responsabilidade de terceiros. Dado o fato de haver atos praticados com excessos de poderes que resultem em obrigações tributárias (critério material), em um determinado período e lugar (critérios temporal e espacial, respectivamente) deve ser (relação deôntica) imputado a terceiro (não contribuinte - sujeito passivo - critério qualitativo) a 
obrigação de recolher certa quantia em dinheiro (critério quantitativo) a determinado ente tributante (sujeito ativo - critério qualitativo).

Neste contexto, serão responsabilizados pessoalmente aqueles que praticaram uma conduta que resultou na existência de créditos correspondentes às obrigações tributárias. O fato ilícito (excesso de poderes ou infração de lei, contrato social ou estatutos) praticado pelo sujeito deve ensejar, necessariamente, o nascimento de uma obrigação tributária.

Entende-se por excesso de poder a prática de ato em nome da sociedade sem observar os limites contidos no contrato social. Por exemplo: diretor de sociedade que adquire imóvel em nome da pessoa jurídica, sabendo que, pelo estatuto social, deveria comunicar previamente aos demais sócios. A dívida de ITBI, devida pelo adquirente, no caso a empresa, poderá recair sobre o diretor.

$\mathrm{Na}$ infração de contrato social ou estatuto, ensina Renato Lopes Becho que pode ocorrer quando um diretor de marketing extrapolar a competência do seu cargo, contraindo dívida financeira em nome da sociedade, considerando que essa atribuição seria do setor financeiro (BECHO, 2014, p. 108).

Quanto ao terceiro requisito, infração à lei, não é qualquer legislação que enseja a aplicação do disposto no art. 135 do CTN. Se assim fosse, uma mera infração à lei de trânsito poderia gerar a responsabilidade tributária do administrador, afastando a obrigatoriedade da pessoa jurídica.

A lei a que se reporta o Código Tributário Nacional pode ser a civil, a financeira, a comercial e, até mesmo, a tributária. Fato é que ela sempre estará vinculada ao exercício da administração e cujo desrespeito à lei implique a ocorrência de fato jurídico tributário, a exemplo: o administrador de uma empresa que efetua a venda de uma mercadoria na fase ainda de registro da pessoa jurídica perante o órgão fazendário. Como não se tem autorização para emitir nota fiscal, esta venda foi efetuada à margem da legislação tributária.

A Corte Superior é pacífica no sentido de admitir como ilícito, para fins de viabilizar a responsabilidade prevista no art. 135 do CTN, o ato omissivo consistente na ausência de repasse das contribuições previdenciárias descontadas no salário dos empregados: 


\begin{abstract}
PROCESSUAL CIVIL. TRIBUTÁRIO. AÇÃO DE DEPÓSITO. RETENÇÃO DE CONTRIBUIÇÃO PREVIDENCIÁRIA SEM REPASSE AO INSTITUTO DE PREVIDÊNCIA SOCIAL. INFRAÇÃO À LEI. APLICAÇÃO DO ART. 135, III, DO CTN. IRREGULARIDADE TRIBUTÁRIA INCONTROVERSA. DESNECESSIDADE DE REVOLVIMENTO FÁTICO-PROBATÓRIO. VIOLAÇÃO AO ART. 1.022 DO CPC/2015. NÃO OCORRÊNCIA. DEMAIS MATÉRIAS DE QUE NÃO SE CONHECE. 1. O Tribunal a quo excluiu a responsabilidade tributária do sócio em relação a contribuição previdenciária descontada (retida) no salário dos empregados e não repassada ao INSS. 2. A orientação do STJ é pacífica no sentido de que constitui ilícito, para fins de viabilizar a responsabilidade das pessoas previstas no art. 135, III, do CTN, o ato omissivo consistente na ausência de repasse das contribuições previdenciárias descontadas no salário dos empregados. 3. A definição da aplicação do art. 135, III, do CTN à hipótese dos autos não implica revolvimento do contexto fático-probatório a esbarrar na Súmula 7/STJ, mas tão somente análise dos efeitos jurídicos de determinada prática que não se controverte na lide. 4. Não configurada a alegada ofensa ao artigo 1.022 do Código de Processo Civil de 2015, uma vez que o Tribunal de origem julgou integralmente a lide e solucionou, de maneira amplamente fundamentada, a controvérsia, em conformidade com o que Ihe foi apresentado. 5. Demais matérias de que não se conhece, seja pela natureza constitucional da discussão sobre a prisão civil do depositário infiel, seja por já reconhecida favoravelmente ao recorrente no Acórdão atacado a adequação da via eleita e a persistência do interesse de agir em relação aos demais efeitos da ação de depósito. 6. Recurso Especial conhecido em parte e, nesta parte, provido. (STJ, 2017, online).
\end{abstract}

É importante deixar registrado que nos termos da Súmula no 430 do STJ o inadimplemento da obrigação tributária pela sociedade não enseja a responsabilidade do administrador com fundamento no art. 135 do CTN $^{8}$.

Em 13 de abril de 2010 a Corte Superior publicou a Súmula № 435 consolidando o entendimento segundo o qual a dissolução irregular da empresa ensejaria a responsabilidade dos sócios para adimplemento da obrigação por força do art. 135, inciso III, do Código Tributário Nacional:

Súmula 435 - Presume-se dissolvida irregularmente a empresa que deixar de funcionar no seu domicílio fiscal, sem comunicação aos órgãos competentes, legitimando o redirecionamento da execução fiscal para o sócio-gerente.

8 "O inadimplemento da obrigação tributária pela sociedade não gera, por si só, a responsabilidade solidária do sócio-gerente" (Súmula 430, PRIMEIRA SEÇÃO, julgado em 24/03/2010, REPDJe 20/05/2010, DJe 13/05/2010). 
$\mathrm{Na}$ ótica do Superior Tribunal de Justiça, a empresa que acabar com suas operações, literalmente "fechando as portas", sem prévia comunicação aos órgãos competentes, legitima o redirecionamento da execução fiscal para o sócio-gerente. A partir de então, cessaria a responsabilidade da empresa (na condição de contribuinte), sendo transferida para o sócio administrador a responsabilidade pelo adimplemento da obrigação tributária.

A interpretação que se faz da Súmula no 435 do STJ é que, ao contrário da norma que lhe deu origem, o que vai ensejar a responsabilidade de terceiro é a dissolução irregular da sociedade. Todavia, este fato, por si só, não enseja o nascimento de qualquer obrigação tributária.

Melhor dizendo, o fechamento não provoca o nascimento de qualquer obrigação tributária, uma vez que tais obrigações, na verdade, são a causa da dissolução da empresa que, na sua maioria das vezes, não suporta a carga tributária, principalmente, em uma época de crise e baixa nas vendas.

Um dos precedentes que deu origem a Súmula foi o voto do Min. Herman Bejamin no EREsp no 716.412/PR. Vale destacar suas palavras:

\begin{abstract}
Hipótese em que o Tribunal a quo decidiu pela responsabilidade dos sóciosgerentes, reconhecendo existirem indícios concretos de dissolução irregular da sociedade por 'impossibilidade de se localizar a sede da empresa, estabelecimento encontrado fechado e desativado, etc.'. 2. Dissídio entre o acórdão embargado (segundo o qual a não-localização do estabelecimento nos endereços constantes dos registros empresarial e fiscal não permite a responsabilidade tributária do gestor por dissolução irregular da sociedade) e precedentes da Segunda Turma (que decidiu pela responsabilidade em idêntica situação). 3. O sócio-gerente que deixa de manter atualizados os registros empresariais e comerciais, em especial quanto à localização da empresa e à sua dissolução, viola a lei (arts. 1.150 e 1.151, do CC, e arts. $1^{\circ}$, 2º , e 32, da Lei 8.934/1994, entre outros). A não-localização da empresa, em tais hipóteses, gera legítima presunção iuris tantum de dissolução irregular e, portanto, responsabilidade do gestor, nos termos do art. 135, III, do CTN, ressalvado o direito de contradita em Embargos à Execução. (STJ, 2008, online).
\end{abstract}

Naquela situação, foi constatado nos autos a existência de indícios concretos de dissolução irregular da sociedade por impossibilidade de localizar a empresa, já que o estabelecimento havia sido encontrado fechado e desativado. Por causa disso, concluiu o llustre Ministro Relator que a não-localização da pessoa 
jurídica permitiria presumir a sua dissolução (irregular) e, como consequência, possibilitaria a responsabilizar o sócio nos termos do art. 135 do CTN.

Ocorre que o fato de o sócio não atualizar seu cadastro perante a Receita Federal, presumindo com isso a dissolução da sociedade (conduta ilícita), não faz surgir a obrigação tributária. O nascimento desta já teria ocorrido previamente ao ato irregular. Por isso, que a Súmula 435 não segue a orientação dada pelo art. 135 do CTN cuja norma impõe a responsabilidade do sócio quando a sua conduta infracional resulta no surgimento da obrigação tributária.

Um outro julgado que ensejou a edição da malsinada Súmula foi o REsp no 1.017.732/RS de relatoria da Ministra Eliana Calmon cuja ementa transcrevo a seguir:

PROCESSO CIVIL E TRIBUTÁRIO - EXECUÇÃO FISCAL - OFENSA AO ART. 535, II DO CPC - INOCORRÊNCIA - DISSOLUĈ̃O IRREGULAR SÓCIO-GERENTE - REDIRECIONAMENTO - INTERPRETAÇÃO DO ART. 135, INCISO III, DO CTN. 1. Não viola o art. 535, II do CPC, tampouco nega a prestação jurisdicional, o acórdão que, embora rejeitando os embargos de declaração, examina motivadamente todas as questões pertinentes. 2. É pacífica a jurisprudência desta Corte no sentido de que o simples inadimplemento da obrigação tributária não caracteriza infração à lei, de modo a ensejar a redirecionamento da execução para a pessoa dos sócios. 3. Em matéria de responsabilidade dos sócios de sociedade limitada, é necessário fazer a distinção entre empresa que se dissolve irregularmente daquela que continua a funcionar. 4 . Em se tratando de sociedade que se extingue irregularmente, impõe-se a responsabilidade tributária do sóciogerente, autorizando-se o redirecionamento, cabendo ao sócio-gerente provar não ter agido com dolo, culpa, fraude ou excesso de poder. 5. A empresa que deixa de funcionar no endereço indicado no contrato social arquivado na junta comercial, desaparecendo sem deixar nova direção, é presumivelmente considerada como desativada ou irregularmente extinta. 6 . Imposição da responsabilidade solidária. 7. Recurso especial parcialmente provido. (STJ, 2008, online)

A ementa acima referendada traz em seu bojo a situação de uma empresa que deixou de funcionar no endereço indicado no contrato social devidamente arquivado na junta comercial, desparecendo sem deixar nova direção razão pela qual foi presumida a dissolução irregular da pessoa jurídica.

Interessante notar que a Ministra afirmou que ainda que a atividade comercial esteja sendo realizada em outro endereço, estaria maculada pela 
informalidade, concretizando o indício de dissolução irregular e, neste caso, a Corte Superior entende que não há necessidade de exigir a comprovação da autuação dolosa, com fraude ou excesso de poderes, por parte dos sócios, para se autorizar o redirecionamento da execução fiscal. Na sua ótica, basta o simples indício de dissolução para legitimar a responsabilidade do sócio.

A distorção da norma complementar se torna ainda mais operante neste julgado que além de não exigir a comprovação da consequência da dissolução (no caso, o nascimento da obrigação tributária), sequer impõe a demonstração da própria infração à lei (fechamento irregular).

Independentemente da causa que tenha ensejado a dissolução irregular, se do ato irregular não fez surgir uma obrigação tributária, o pedido de redirecionamento fundado no art. 135, inciso III, do CTN deve ser indeferido, afastando a incidência da Súmula STJ 435.

Como ressalta Hugo de Brito Machado (2000, p.127):

\begin{abstract}
Importante notar-se que a responsabilidade dos sócios-gerentes, diretores e administradores de sociedade, nos termos do art. 135, III, CTN, é por obrigações resultantes de atos praticados com excesso de poderes ou infração de lei, contrato social ou estatutos. Poder-se-ia, assim, sustentar que a obrigação, pela qual respondem, há de ser resultante de atos irregularmente praticados. $\mathrm{O}$ próprio nascimentos da obrigação tributária já teria de ser em decorrência de atos irregulares.
\end{abstract}

O equívoco na aplicação do art. 135, inciso III, do CTN, desaguando na Súmula № 435 do STJ, induz à conclusão de que o fechamento irregular da empresa denotaria sinais de riqueza (aplicação do princípio da capacidade contributiva) daquele que a provoca capaz de responsabiliza-lo pelo adimplemento da obrigação, o que, de certo, não é possível!

A hipótese referida deve ser rechaçada principalmente porque o responsável pelo fechamento da empresa não necessariamente responderá pela obrigação tributária.

Neste sentido, a Primeira Turma da Corte Superior a responsabilidade dos sócios exige a contemporaneidade da gerência, direção ou representação da pessoa 
jurídica executada com a data do fato gerador, independentemente da concomitância com a ocorrência do fechamento irregular:

TRIBUTÁRIO. EXECUÇÃO FISCAL. PRESUNÇÃO DE DISSOLUÇÃO IRREGULAR DA SOCIEDADE. REDIRECIONAMENTO. GERÊNCIA NÃO EXERCIDA À ÉPOCA DOS FATOS GERADORES DOS DÉBITOS. IMPOSSIBILIDADE. 1. A atribuição de responsabilidade pessoal prevista no art. 135, III, do CTN, ainda que em razão da dissolução irregular da sociedade empresária, exige a contemporaneidade da gerência com o momento da ocorrência do fato gerador do tributo não adimplido, visto que a responsabilidade atribuída ao sócio deriva, especificamente, do inadimplemento ocasionado pelos atos de gerência abusivos e/ou ilegais. 2. Hipótese em que o acórdão recorrido, ao decidir pelo não redirecionamento, constatou que o sócio, cuja responsabilização é requerida, não exercia a administração da sociedade empresária à época dos fatos geradores. 3 . Agravo conhecido para desprover o recurso especial. (STJ, 2016, online).

Na situação tratada no julgado acima transcrito, seria até difícil aplicar a Súmula ํo 435 do STJ porque a obrigação tributária além de ter surgido em momento anterior à dissolução, o sujeito que provocou a extinção da empresa difere daquele responsável pela materialidade do fato imponível. Nem sempre quem realiza o fato gerador é aquele quem promove a dissolução da empresa.

Em sentido diverso, a Segunda Turma da Corte Superior autoriza o redirecionamento ao sócio, detentor do poder de gerência, responsável pela dissolução irregular da empresa (ou sua presunção - Súmula 435 STJ), sendo irrelevante a data do fato gerador da obrigação tributária não adimplida. Eis o entendimento atual adotado após o julgamento do REsp no 1.520.257/SP de relatoria do Ministro Og Fernandes.

Como forma de delimitar a controvérsia, em 13 de setembro de 2017, a Primeira Seção aceitou a proposta de afetação do REsp no $1.645 .333 / \mathrm{SP}$ (Informativo № 0609) para julgamento sob o rito de recurso repetitivo (art. 1.036, $\S 1^{\circ}$ do $\mathrm{CPC} / 15)$. Na ocasião, será decidido se o pedido de redirecionamento do sócio fundado no art. 135, inciso III, do CTN, quando irregularmente dissolvida a empresa ou, pelo menos, presumida sua ocorrência (Súmula 435 STJ), deve ser autorizado contra o sócio com poderes de administração da sociedade, na data em que configurada a sua dissolução irregular ou a presunção de sua ocorrência e, 
concomitantemente, tenha exercido poderes de gerência na data em que ocorrido o fato gerador da obrigação tributária não adimplida (1 $1^{\underline{a}}$ situação) ou contra o sócio com poderes de administração da sociedade, na data em que configurada a sua dissolução irregular ou a presunção de sua ocorrência (Súmula 435/STJ), ainda que não tenha exercido poderes de gerência, na data em que ocorrido o fato gerador do tributo não adimplido ( $2^{\mathrm{a}}$ situação $)^{9}$.

Qualquer um dos dois posicionamentos, não se alinham à norma instituída no art. 135, inciso III, do CTN. Primeiro porque a dissolução irregular (ou mesmo a sua presunção), por si só, não resulta no nascimento de obrigação tributária. Em segundo lugar, na dicção do art. 128 do CTN, o responsável tributário deve ser vinculado ao fato gerador da respectiva obrigação, porém, nem sempre o responsável pelo surgimento da obrigação tributária estava na sociedade ao tempo da sua dissolução irregular.

A desconsideração da personalidade jurídica sob o enfoque tributário da responsabilização dos sócios-administradores vem sendo aplicado pelo Judiciário sem critério. Neste sentido são as palavras de Estevão Horvath e Pedro Satiro (2015, p.83):

[...] há muito tempo o instituto da desconsideração da personalidade jurídica sob o enfoque tributário com a responsabilização dos sóciosadministradores vem sendo aplicado pelo Poder Judiciário de maneira descriteriosa e equivocada, pois, tão logo reste infrutífera a exigência fiscal por meio da ação executiva em razão de não se encontrar bens ou direitos em nome da empresa, ou mesmo por encerramento irregular, o sujeito ativo da obrigação tributária se vê no direito de exigir dos sócios proprietários, gestores e administradores de pessoa jurídica referida dívida, sem qualquer fundamento que justifique tal redirecionamento.

E esse entendimento da Corte Superior acabou por influenciar o Conselho Administrativo de Recursos Fiscais da Receita Federal (CARF), levando à interpretação equivocada.

No julgamento proferido pela 4⿳亠丷a Câmara da 1aㅡ Turma Ordinária, no AC no 1401001.220 (PAF no 15521.000170/2010-62), em 29.07.2014, foi dito que os

${ }^{9}$ Proposta de Afetação no REsp no $1645333 / \mathrm{SP}$ 
elementos constantes dos autos foram amplamente suficientes para demonstrar que, na espécie, ocorreram atos ilícitos, caracterizados pela dissolução irregular da pessoa jurídica e pela utilização de interpostas pessoas. Mais adiante concluiu que o art. 135 do CTN seria plenamente aplicável ao presente caso, uma vez comprovados, cumulativamente i) o exercício de atividade de administração ou gerência, por parte das pessoas físicas apontadas como responsáveis solidárias; ii) a ocorrência de infração à lei ou excesso de poderes, caracterizada pela dissolução irregular da sociedade. Vide transcrição do voto:

Os elementos constantes dos autos são amplamente suficientes para demonstrar que, na espécie, ocorreram atos ilícitos, caracterizados pel a dissolução irregular da pessoa jurídica e pela utilização de interpostas pes soas.[...]Concluo que o art. 135, II do CTN é plenamente aplicável ao presen te caso, uma vez comprovados, cumulativamente: i) o exercício de atividade de administração ou gerência por parte das pessoas físicas apontadas como responsáveis solidárias; ii) a ocorrência de infração à lei ou excesso de poderes, caracterizada pela dissolução irregular da sociedade (CARF, 2015, online).

Mais uma vez o Tribunal Administrativo eleva à hipótese de incidência o fato de a empresa ser dissolvida irregularmente. Porém, isto, por si só, não faz nascer a obrigação tributária instituída no art. 135 do CTN (abre-se um parêntese para o fato de que o leading case traz em seu bojo o inciso II como fundamento do redirecionamento, contudo, a análise da matéria ficou restrita ao inciso III por se tratar de redirecionamentos para os administradores).

Interessante examinar o AC ํㅜ 3402-004.962 proferido pela 4 Câmara da $2^{\mathrm{a}}$ Turma Ordinária no PAF no 13864.720216/2014-81 cujo julgamento abordou a questão da responsabilidade solidária sob o enfoque da dissolução irregular da sociedade como consequência do ato praticado com excesso de poderes ou infração à lei, contrato social ou estatuto:

RESPONSABILIDADE DE TERCEIROS. ART. 135 DO CTN. ADMINISTRADOR DE FATO. EXCESSO DE PODERES, INFRAÇÃO DE LEI, CONTRATO SOCIAL OU ESTATUTO. DISSOLUÇÃO IRREGULAR DA EMPRESA. Nos termos do art. 135 do CTN, responde pelos tributos devidos pela pessoa jurídica extinta o administrador, inclusive de fato, por atos praticados com excesso de poderes ou infração de lei, contrato 
social ou estatutos, o que resta caracterizado pela comprovação da dissolução irregular da empresa. (CARF, 2018, online)

No caso acima, a extinção da sociedade decorreu de práticas abusivas de seus administradores o que resultou na transferência da responsabilidade tributária. Porém, em nenhum momento da autuação fora comprovado que este ato deu origem a eventual obrigação tributária. Ao que parece, a dívida existia previamente à extinção da empresa.

Observe que ainda que 0 enunciado da Súmula não tenha sido expressamente citado no julgamento, a interpretação dada ao disposto no art. 135 do Código Tributário Nacional segue a orientação, ainda que equivocada, firmada pelo Superior Tribunal de Justiça.

Este artigo não pretende abordar o tema da dissolução irregular da empresa como defesa de um calote generalizado. A única pretensão é interpretar corretamente a norma e, a partir disso, mitigar a aplicação da Súmula ํㅡㄴ 435 do STJ, dando a esta a extensão e amplitude adequada.

A responsabilização do sócio com base na malsinada Súmula não encontra amparo na legislação tributária em vigor, nem, muito menos, na Constituição Federal. Trata-se, a bem da verdade, de uma nova hipótese de responsabilidade instituída sem amparo na norma complementar, em completo desrespeito ao disposto no art. 146, inciso III, alínea 'b' da Carta Republicana de 1988.

E por assim dizer, a dissolução irregular da empresa não enseja o redirecionamento do sócio administrador por força de eventual dissolução da empresa por carecer de norma jurídica autorizadora.

\subsection{FINALIDADE DA SÚMULA 435 DO STJ}

Ao que nos parece a Súmula o 435 do STJ foi publicada como uma forma de solucionar um problema enfrentado pelos entes tributantes. A alta carga tributária e a crise econômica encarada pelas empresas afetaram os cofres públicos em decorrência da falta de recolhimento dos tributos. 
A isso acrescente o volume de ações executivas ajuizadas diariamente pelas Procuradorias das Fazendas que se somam a outras milhares de demandas já existentes, embaraçando os cartórios ante a falta de servidores suficientes para agilizarem a tramitação do processo. Isso resulta em consequências danosas à efetividade da citação da pessoa jurídica que, pelo tempo, já não suporta manter suas atividades comerciais.

As tentativas frustradas das Fazendas Públicas em buscar meios de garantir o crédito tributário não mais surtiam efeito. Não havendo recursos para operacionalizar a atividade econômica, é óbvio que a penhora de faturamento, BACENJUD ${ }^{10}$, RENAJUD ${ }^{11}$ ou imóveis cada vez mais se tornava inoperante ${ }^{12}$.

Mais tarde, a solução foi dada pelo Superior Tribunal de Justiça através de uma interpretação equivocada do art. 135, III, do CTN. A fim de garantir o recebimento do valor, achou por bem consolidar o entendimento segundo o qual a dissolução da sociedade de forma irregular, por afrontar a legislação, ensejaria o redirecionamento da obrigação aos administradores integrantes do quadro societário.

Esqueceu a Corte Superior que a norma complementar só autoriza o redirecionamento quando $o$ ato praticado pelo administrador resultar no nascimento da obrigação tributária.

Não pode imputar à sujeição passiva a terceira pessoa desvinculada ao fato gerador diante da norma estabelecida no art. 121, parágrafo único, inciso II, do CTN. Até porque, como já afirmado anteriormente, o legislador não tem liberdade de escolha do sujeito passivo da obrigação tributária, porquanto a materialidade do tributo indicada pela norma constitucional o vincula, tolhendo-lhe a liberdade de eleger qualquer um como responsável.

Conforme esclarece Renato Lopes Becho (2014, p.16):

\footnotetext{
10 Penhora online diretamente na conta bancária da empresa.

11 Penhora de veículos da empresa perante os órgãos de trânsito.

12 Relatório da PGFN divulgou recentemente estoque da dívida ativa da União em 2017 em torno de $R \$ 2$ trilhões, dos quais foram recuperados no ano $R \$ 26,1$ bilhões. Portanto, apenas $1,3 \%$ da dívida é recuperado anualmente. (BRASIL, 2018).
} 


\begin{abstract}
Com isso, o legislador não tem liberdade de escolha do sujeito passivo da obrigação tributária. A Constituição já traz, implicitamente, o sujeito passivo dos impostos discriminados, traz os dados para a sua identificação. Ela não é mero referencial para o legislador ordinário. Tais afirmativas são deduções do sistema tributário que está disposto na Constituição Federal. O art. 146 ordena o legislador infraconstitucional que edite lei complementar dispondo sobre os vários institutos de direito tributário, inclusive definindo os contribuintes dos impostos discriminados constitucionalmente (inc. III, letra a) $\ldots$
\end{abstract}

Como se vê, não compete ao Judiciário criar hipótese de responsabilidade tributária desvirtuando aquela prescrita na norma complementar por força do disposto no art. 146 da Constituição Federal.

\title{
3.3 DA DISSOLUÇÃO DA EMPRESA AUTORIZADA POR LEI:
}

A Súmula 435 STJ foi publicada como forma de fomentar a arrecadação quando encerrada a atividade da empresa irregularmente.

A forma indiscriminada da sua incidência gerou distorções sem precedentes na forma de cobrança dos tributos.

A anomalia interpretativa chega ao seu ápice se considerar o fato de algumas empresas não conseguirem manter os custos financeiros para o funcionamento mínimo de operacionalização e, apesar disso, por força da existência de débitos tributários, previdenciários e trabalhistas são impedidas de encerrar as atividades.

Para tentar aliviar esta situação foi promulgada a Lei Complementar № 147 de 07 e agosto de 2014 que incluiu o art. 7-A à Lei no 11.598/07. De acordo com a norma, o registro dos atos constitutivos, de suas alterações e extinções (baixas), referentes a empresários e pessoas jurídicas em qualquer órgão dos três âmbitos de governo, ocorrerá independentemente da regularidade de obrigações tributárias, previdenciárias ou trabalhistas, principais ou acessórias, do empresário, da sociedade, dos sócios, dos administradores ou de empresas de que participem, sem prejuízo das responsabilidades do empresário, dos titulares, dos sócios ou 
dos administradores por tais obrigações, apuradas antes ou após o ato de extinção.

Reza o parágrafo primeiro do art. 7-A da Lei Ordinária de 2014 que a baixa da empresa não impede que, posteriormente, sejam lançados ou cobrados impostos, contribuições e respectivas penalidades, decorrentes da simples falta de recolhimento ou da prática comprovada e apurada em processo administrativo ou judicial de outras irregularidades praticadas pelos empresários ou por seus titulares, sócios ou administradores.

Nesta circunstância o contribuinte poderá se valer de dois caminhos: ou encerra irregularmente a empresa, sem baixa no registro e, com isso, à luz da famigerada Súmula fica o sócio administrador responsável pessoalmente pelas dívidas tributárias da empresa, ainda que esta dissolução não seja a causa do nascimento da obrigação; ou providencia a baixa do registro e, neste caso, o sócio, independentemente do poder de gestão e da contemporaneidade do faro gerador, passa a ser solidariamente responsável pelas dívidas de natureza tributária, previdenciária e trabalhista pertencentes à pessoa jurídica (art. $7^{\circ}-\mathrm{A}, \S^{\circ}{ }^{\circ}$ da Lei $n^{\circ}$ 11.598/07).

Para se esquivar da responsabilidade solidária e fugir da aplicação indiscriminada da Súmula 435 do STJ, a única saída para o empresário, para o fim de preservar seu patrimônio, seria o pedido de decretação de falência.

Consoante art. 77 da Lei o 11.101/05 a falência, ao promover o afastamento do devedor de suas atividades, visa a preservar e otimizar a utilização produtiva dos bens, ativos e recursos produtivos, inclusive os intangíveis, da empresa.

Nas sociedades de responsabilidade limitada, a responsabilização dos sócios, controladores e administradores da sociedade falida será apurada no juízo de falência somente quando houver fraude no procedimento (art. 82 da Lei no 11.101/05).

O fechamento regular da empresa pela decretação da falência afasta a aplicação da Súmula 435 STJ.

A Corte Superior, em sede de recurso repetitivo, tema 630, abordou o assunto sustentando a obrigação dos gestores da empresa em manter atualizados 
os respectivos cadastros, incluindo os atos relativos à mudança de endereço dos estabelecimentos e, especialmente, referentes à dissolução da sociedade. A regularidade desses registros seria exigida para a demonstração de que a sociedade dissolveu-se de forma regular, em obediência aos ritos e formalidades previstas nos arts. 1.033 à 1.038 e arts. 1.102 a 1.112, todos do Código Civil de 2002 - onde é prevista a liquidação da sociedade com o pagamento dos credores em sua ordem de preferência - ou na forma da Lei no $11.101 / 2005$, no caso de falência. De tal sorte que a desobediência a tais ritos restaria caracterizada a infração à lei.

PROCESSUAL CIVIL. TRIBUTÁRIO. RECURSO ESPECIAL REPRESENTATIVO DA CONTROVÉRSIA. ART. 543-C, DO CPC. REDIRECIONAMENTO DE EXECUÇÃO FISCAL DE DÍVIDA ATIVA NÃOTRIBUTÁRIA EM VIRTUDE DE DISSOLUÇÃO IRREGULAR DE PESSOA JURÍDICA. POSSIBILIDADE. ART. 10, DO DECRETO N. 3.078/19 E ART. 158, DA LEI N. 6.404/78 - LSA C/C ART. 4ํ, V, DA LEI N. 6.830/80 - LEF. 1. A mera afirmação da Defensoria Pública da União - DPU de atuar em vários processos que tratam do mesmo tema versado no recurso representativo da controvérsia a ser julgado não é suficiente para caracterizar-lhe a condição de amicus curiae. Precedente: REsp. 1.333.977/MT, Segunda Seção, Rel. Min. Isabel Gallotti, julgado em 26.02.2014. 2. Consoante a Súmula n. 435/STJ: "Presume-se dissolvida irregularmente a empresa que deixar de funcionar no seu domicílio fiscal, sem comunicação aos órgãos competentes, legitimando o redirecionamento da execução fiscal para o sócio-gerente". 3. É obrigação dos gestores das empresas manter atualizados os respectivos cadastros, incluindo os atos relativos à mudança de endereço dos estabelecimentos e, especialmente, referentes à dissolução da sociedade. A regularidade desses registros é exigida para que se demonstre que a sociedade dissolveu-se de forma regular, em obediência aos ritos e formalidades previstas nos arts. 1.033 à 1.038 e arts. 1.102 a 1.112, todos do Código Civil de 2002 - onde é prevista a liquidação da sociedade com o pagamento dos credores em sua ordem de preferência - ou na forma da Lei n. 11.101/2005, no caso de falência. A desobediência a tais ritos caracteriza infração à lei. 4. Não há como compreender que o mesmo fato jurídico "dissolução irregular" seja considerado ilícito suficiente ao redirecionamento da execução fiscal de débito tributário e não o seja para a execução fiscal de débito não-tributário. "Ubi eadem ratio ibi eadem legis dispositio". O suporte dado pelo art. 135, III, do CTN, no âmbito tributário é dado pelo art. 10, do Decreto n. 3.078/19 e art. 158, da Lei n. 6.404/78 - LSA no âmbito não-tributário, não havendo, em nenhum dos casos, a exigência de dolo. 5. Precedentes: REsp. n. 697108 / MG, Primeira Turma, Rel. Min. Teori Albino Zavascki, julgado em 28.04.2009; REsp. n. 657935 / RS , Primeira Turma, Rel. Min. Teori Albino Zavascki, julgado em 12.09.2006; AgRg no AREsp 8.509/SC, Rel. Min. Humberto Martins, Segunda Turma, DJe 4.10.2011; REsp 1272021 / RS, Segunda Turma, Rel. Min. Mauro Campbell Marques, julgado em 07.02.2012; REsp 1259066/SP, Terceira Turma, Rel. Min. Nancy Andrighi, DJe 28/06/2012; REsp.n. ㅇ 1.348.449 - RS, Quarta Turma, Rel. Min. Luis Felipe Salomão, julgado em 
11.04.2013; AgRg no AG o 668.190 - SP, Terceira Turma, Rel. Min. Ricardo Villas Bôas Cueva, julgado em 13.09.2011; REsp. n.ำ 586.222 - SP, Quarta Turma, Rel. Min. Luis Felipe Salomão, julgado em 23.11.2010; REsp 140564 / SP, Quarta Turma, Rel. Min. Barros Monteiro, julgado em 21.10.2004. 6. Caso em que, conforme o certificado pelo oficial de justiça, a pessoa jurídica executada está desativada desde 2004, não restando bens a serem penhorados. Ou seja, além do encerramento irregular das atividades da pessoa jurídica, não houve a reserva de bens suficientes para o pagamento dos credores. 7. Recurso especial provido. Acórdão submetido ao regime do art. 543-C do CPC e da Resolução STJ 08/2008. (STJ, 2014, online).

$\mathrm{Na}$ maioria das vezes, a dissolução irregular dá-se com o abandono da sociedade ou a transferência mediante simulação de sua titularidade a terceiros, que, consciente ou inconscientemente, apenas "emprestam o nome" para fins de registro comercial e fiscal e não têm capacidade para arcar com as dívidas da sociedade empresária (MARINS, 2009, p. 171).

Isso não é possível quando se está a preservar o patrimônio do sócio em detrimento da arrecadação.

Desse modo, qualquer que seja o fundamento do pedido de redirecionamento, é certo que os enunciados que o autorizam seguem na mesma perspectiva, impor o adimplemento da obrigação tributária nem que para isso repute responsável é aquele que sequer possui nexo causal com o fato gerador (basta permanecer na sociedade ao tempo da dissolução irregular).

\section{CONCLUSÃO}

A análise da sujeição passiva tributária deve partir da interpretação das normas constitucionais, já que é ela que delimita a regra matriz de incidência tributária dos impostos trazendo em seu bojo, ainda que implicitamente, os dados para caracterização do sujeito passivo de modo a evitar que o legislador infraconstitucional atribua a qualquer um a obrigação tributária.

A responsabilidade tributária está vinculada aos princípios constitucionais da capacidade contributiva (art. 145, $\S^{\circ}$ da Constituição Federal), ao princípio da 
segurança jurídica e da não surpresa; ao princípio da legalidade (art. 150, inciso I, da Constituição Federal) e, não menos importante, ao princípio do não confisco (art. 150, inciso IV, da Constituição Republicana).

Importa ressaltar que os tributos cuja materialidade não esteja especificada na Constituição Federal, a exemplo: taxa, contribuição de melhoria ${ }^{13}$ e impostos de competência residual ${ }^{14}$, não foge à regra e, por isso, a sujeição passiva também fica associada à materialidade do tributo. Como exemplo, temos a taxa de vigilância sanitária instituída pelo art. 23 da Lei ํㅜ 9.782/99.

De acordo com a norma, a exação é devida por pessoa física e jurídica que exerça atividade de fabricação de cosmético. Neste contexto, a norma indica como fato gerador (materialidade do tributo) a prática de atos de competência da Agência Nacional de Vigilância Sanitária (órgão responsável pela fiscalização). Aquele que realiza o fato gerador (da hipótese de incidência da taxa - de fiscalização) está obrigado ao recolhimento do referido tributo.

A responsabilidade tributária também pode ser analisada na ótica de terceiros não contribuintes. A despeito de inexistir relação direta e pessoal com o fato gerador, nem por isso o legislador infraconstitucional teria ampla liberdade de apontar qualquer sujeito para integrar a relação jurídico-tributária. Permanece a vinculação do terceiro (não-contribuinte) à materialidade do tributo. A Carta Republicana reconhece a sua existência e o vincula ao fato gerador, a exemplo do art. $150, \S^{\circ}$ da CF.

Seguindo a ordem constitucional estabelecida no art. 146, inciso III, alínea 'a' da Constituição Federal, dispõe o art. 121, inciso II, do CTN que o sujeito passivo

\footnotetext{
${ }^{13}$ Os proprietários de imóveis situados nas zonas beneficiadas pelas obras públicas - decreto lei oㅡㄴ $195 / 67$.

${ }^{14}$ Art. 154. A União poderá instituir: I - mediante lei complementar, impostos não previstos no artigo anterior, desde que sejam não-cumulativos e não tenham fato gerador ou base de cálculo próprios dos discriminados nesta Constituição; II - na iminência ou no caso de guerra externa, impostos extraordinários, compreendidos ou não em sua competência tributária, os quais serão suprimidos, gradativamente, cessadas as causas de sua criação. Art. 195. A seguridade social será financiada por toda a sociedade, de forma direta e indireta, nos termos da lei, mediante recursos provenientes dos orçamentos da União, dos Estados, do Distrito Federal e dos Municípios, e das seguintes contribuições sociais: ... $\S 4^{\circ} \mathrm{A}$ lei poderá instituir outras fontes destinadas a garantir a manutenção ou expansão da seguridade social, obedecido o disposto no art. 154, I.
} 
deve ter ligação com o fato gerador e se não revestir a condição de contribuinte, mas se a obrigação decorrer de lei, diz-se terceiro.

Os arts. 134 e 135 do CTN dispõem sobre a responsabilidade de terceiros. Considerando a aplicação do disposto no art. 135, inciso III, do CTN, a Corte Superior publicou a Súmula ํo 435 consolidando o entendimento segundo o qual a dissolução irregular da empresa ensejaria a responsabilidade dos sócios para adimplemento da obrigação tributária.

A interpretação que se faz da Súmula no 435 do STJ é que, ao contrário da norma que lhe deu origem, o que vai ensejar a responsabilidade de terceiro é a dissolução irregular da sociedade. Todavia, este fato, por si só, não enseja o nascimento de qualquer obrigação tributária.

Ao que me parece a Súmula № 435 do STJ foi publicada como uma forma de arrecadar em vista da crise econômica enfrentada pelas empresas e do acúmulo de processos que assolam o Poder Judiciário dificultando a rápida solução do litígio.

Longe de ser resolvida a problemática, o que se espera dos Tribunais (Judicial e Administrativo) é a correta aplicação da legislação hodierna para que evite interpretações distorcidas com a única finalidade de fomentar a arrecadação em benefício dos cofres públicos.

\section{REFERÊNCIAS}

$\mathrm{BECHO}$, Renato Lopes. Responsabilidade tributária de terceiros: CTN, arts. 134 e 135. São Paulo: Saraiva, 2014;

FERRAGUT, Maria Rita. Responsabilidade tributária e o Código Civil de 2002. 1. Ed. São Paulo: Noeses, 2005;

QUEIROZ, Mary Elbe e JÚNIOR, Benedicto Celso Benício. Responsabilidade de sócios e administradores nas autuações fiscais, volume 2. São Paulo: Foco Fiscal, 2015;

MACHADO, Hugo de Brito. Curso de Direito Tributário, 18 ed., Ed. Malheiros, 2000 , p. 12; 
MARINS, James. Defesa e Vulnerabilidade do contribuinte. São Paulo: Dialética, 2009, p. 171.

BRASIL. Constituição da República Federativa do Brasil, de 05 de outubro de 1988.

http://www.planalto.gov.br/ccivil_03/constituicao/constituicaocompilado.htm.Acessad o em: 24 ago. 2018;

Emenda Constitucional no 20, de 15 de dezembro de 1998. Disponível em:

http://www.planalto.gov.br/CCIVIL_03/Constituicao/Emendas/Emc/emc20.htm.Acess ado em: 24 ago. 2018;

. Lei no 5.172, de 25 de outubro de 1966. Diário Oficial da União, Brasília, 27 out. 1966. Disponível em: http://www.planalto.gov.br/ccivil 03/leis/L5172.htm. Acessado em: 24 ago. 2018;

. Lei no 9.783, de 28 de janeiro de 1999. Diário Oficial da União, Brasília, 28 jan. 1999. Disponível em: http://www.planalto.gov.br/ccivil_03/leis/L9783.htm. Acessado em: 24 ago. 2018;

. Lei no 10.406, de 10 de janeiro de 2002. Diário Oficial da União, Brasília, 11 jan. 2002.2 Disponível em: http://www.planalto.gov.br/ccivil_03/leis/2002//10406.htm. Acessado em: 24 ago. 2018;

. Lei no 11.101, de 9 de fevereiro de 2005. Diário Oficial da União, Brasília, 9 fev. 2005. Disponível em: http://www.planalto.gov.br/ccivil_03/_Ato20042006/2005/Lei/L11101.htm. Acessado em: 24 ago. 2018;

. Lei no 11.598, de 3 de dezembro de 2007. Diário Oficial da União, Brasília, 3 dez. 2007. Disponível em: http://www.planalto.gov.br/ccivil_03/_ato20072010/2007/lei//11598.htm. Acessado em: 24 ago. 2018;

Lei no 13.105, de 16 de março de 2015. Diário Oficial da União, Brasília, 17 mar. 2015. Disponível em: http://www.planalto.gov.br/ccivil_03/_Ato20152018/2015/Lei/L13105.htm. Acessado em: 24 ago. 2018;

. Procuradoria-Geral da Fazenda Nacional. PGFN em números 2018. $2018 . \quad$ Disponível em: http://www.pgfn.fazenda.gov.br/acesso-ainformacao/institucional/pgfn-em-numeros-

2014/pgfn_em_numeros_final_2_web.pdf/view

Súmula 435 expedida pelo Superior Tribunal de Justiça. Primeira Seção. Julgado em 14/04/2010. DJe: 13/05/2010. Disponível em: 
http://www.stj.jus.br/SCON/sumanot/toc.jsp?livre=\%28sumula\%20adj1\%20\%27435\% 27\%29.sub.\#TIT1TEMA0. Acessado em: 24 ago. 2018;

Súmula 430 expedida pelo Superior Tribunal de Justiça. Primeira Seção. Julgado em 24/03/2010. DJe: 13/05/2010, ed. 576. Republicado no DJe: 19/05.2010, ed. $580 . \quad$ Disponível em: https://ww2.stj.jus.br/docs_internet/revista/eletronica/stj-revista-sumulas2014_41_capSumula430.pdf. Acessado em: 24 ago. 2018;

STF. EMBARGOS DECLARATÓRIOS NO AGRAVO REGIMENTAL NO AGRAVO DE INSTRUMENTO: Al 738.163 AgR-ED. Relator: Ministro Gilmar Mendes. DJe no 40: 28.02.2011. Ementário no 2473-2. Disponível em: http://redir.stf.jus.br/paginadorpub/paginador.jsp?docTP=AC\&docID=619830.

Acessado em 24 ago. 2018;

ADI 1102. Relator Ministro Maurício Corrêa. Tribunal Pleno. DJ: 16.10.1995. Disponível em: https://stf.jusbrasil.com.br/jurisprudencia/745237/acaodireta-de-inconstitucionalidade-adi-1102-df. Acessado em 24 ago. 2018.

STJ. RECURSO ESPECIAL: REsp 1674550 SP 2017/0124435-2. Relator: Ministro Herman Benjamin. DJe: 12/09/2017. Disponível em: https://ww2.stj.jus.br/processo/revista/documento/mediado/?componente=ATC\&sequ encial $=74395310 \&$ num_registro $=201701244352 \&$ data $=20170913 \&$ tipo $=51 \&$ formato $=$ PDF. Acessado o em: 24 ago. 2018;

PROPOSTA DE AFETAÇÃO NO RECURSO ESPECIAL: ProAfr no REsp 1645333 SP 2016/0320985-6. Primeira Seção. Relatora Ministra Assussete Magalhães. $\quad$ DJe: 24/08/2017. Disponível em: https://ww2.stj.jus.br/processo/revista/documento/mediado/?componente=ATC\&sequ encial $=72331269 \&$ num_registro $=201603209856 \&$ data $=20170824 \&$ tipo $=51 \&$ formato $=$ PDF. Acessado o em: 24 ago. 2018;

AGRAVO EM RECURSO ESPECIAL: AREsp 838948 SC 2016/00082810. Relator Ministro Gurgel de Faria. DJe: 19/10/2016. Disponível em: https://ww2.stj.jus.br/processo/revista/documento/mediado/?componente=ATC\&sequ encial $=63855685 \&$ num_registro $=201600082810 \&$ data $=20161019 \&$ tipo $=51 \&$ formato $=$ PDF. Acessado o em: 24 ago. 2018;

RECURSO ESPECIAL: REsp 1541275 PR 2015/0124477-2. Relator: Ministro Mauro Campbell Marques. DJe: 17/12/2015. Disponível em: https://ww2.stj.jus.br/processo/revista/documento/mediado/?componente=ATC\&sequ encial $=56188850 \&$ num_registro $=201501244772 \&$ data $=20151218 \&$ tipo $=91 \&$ formato $=$ PDF. Acessado o em: 24 ago. 2018;

RECURSO ESPECIAL: REsp 1520257 SP 2015/00530663. Segunda TurmaRelator Ministro OG Fernandes. DJe: 23/06/2015. Disponível em: 
https://ww2.stj.jus.br/processo/revista/documento/mediado/?componente=ATC\&sequ encial $=47909886 \&$ num_registro $=201500530663 \&$ data $=20150623 \&$ tipo $=51 \&$ formato $=$ PDF. Acessado o em: 24 ago. 2018;

. RECURSO ESPECIAL: REsp 1371128 RS 2013/0049755-8. Relator

Ministro Mauro Campbell Marques. DJe: 17/09/2014. Disponível em: https://ww2.stj.jus.br/processo/revista/documento/mediado/?componente=ATC\&sequ encial $=38179255 \&$ num_registro $=201300497558 \&$ data $=20140917 \&$ tipo $=91 \&$ formato $=$ PDF. Acessado o em: 24 ago. 2018

EMBARGOS DE DIVERGÊNCIA EM RECURSO ESPECIAL: EREsp 716412 PR 2005/0095982-9. Relator: Ministro Herman Benjamin. DJe: 19/09/2008. Disponível em: https://ww2.stj.jus.br/processo/revista/documento/mediado/?componente=ATC\&sequ encial $=2992580$ \&num_registro $=200500959829 \&$ data $=20080922 \&$ tipo $=51 \&$ formato $=P$ DF. Acessado o em: 24 ago. 2018;

. RECURSO ESPECIAL: REsp 1017732 RS 2007/0303820-3. Segunda Turma. Relatora Ministra Eliana Calmon. DJe: 07/04/2008. Disponível em: https://ww2.stj.jus.br/processo/revista/documento/mediado/?componente=ATC\&sequ encial $=3744953 \&$ num_registro $=200703038203 \&$ data $=20080407 \&$ tipo $=51$ \&formato $=P$ DF. Acessado o em: 24 ago. 2018;

CARF. RECURSO VOLUNTÁRIO. AC 3402-004.962 PAF 13864.7202126/2014-81. Terceira Seção de Julgamento Quarta Câmara Segunda Turma Ordinária. Relator Jorge Olmiro Lock Freire. Publicada no site do CARF: 02/04/2018. Disponível em: file:///C:/Users/Juliana\%20Cruz/Downloads/Decisao_13864720216201481.PDF. Acessado o em: 24 ago. 2018;

\section{RECURSO VOLUNTÁRIO. AC 1401-001.220 PAF 15521.000170/2010-}

62. Primeira Seção de Julgamento Quarta Câmara Primeira Turma Ordinária. Relator Fernando Luiz Gomes de Mattos. Publicada no site do CARF: 09/09/2015. Disponível em: https://ww2.stj.jus.br/processo/revista/documento/mediado/?componente=ATC\&sequ encial $=47909886 \&$ num_registro $=201500530663 \&$ data $=20150623 \&$ tipo $=51 \&$ formato $=$ PDF. Acessado o em: 24 ago. 2018; 